spraying with a formulation containing arsenic. It would thus appear that the effect is not confined to sprays containing mercury. The mechanism of this effect, together with other aspects of the phenomenon, are being studied.

Coffee Berry Disease Research Unit,

K. R. Bock

Department of Agriculture,

Coffee Research Station,

Department of Agriculture,

J. B. D. RoBINSON

East African Agriculture and

Forestry Research Organisation, Muguga, Kenya.

\section{Labelling of Cells in Thoracic Duct Lymph of the Guinea Pig after Tritiated Thymidine}

SINCE tritium gives precise localization in radioautographs ${ }^{1}$, and in view of the fact that thymidine is generally believed to be specifically incorporated into deoxyribonucleic acid ${ }^{2}$, tritiated thymidine has been employed in recent years to an increasing extent for the study of cellular proliferation.

The studies now reported have been conducted on a series of 22 male guinea pigs, of mixed strain, weighing approximately $400 \mathrm{gm}$. each. Tritiated thymidine with specific activity of either 0.36 or 1.9 curies $/ \mathrm{m} M$. was given in doses of $1 \mu \mathrm{c}$. per gm. body-weight, and thoracic duct lymph and blood were studied in smear preparations at various periods afterwards. Suspensions and sections were also prepared of thymus, cervical and mesenteric lymph nodes, spleen and bone marrow. Coated radioautographs were prepared by the method of Belanger and Leblond ${ }^{3}$.

Labelled lymphocytes began to appear in lymph during the first hour after the administration of tritiated thymidine, and were thereafter present for several days. To begin with, labelled large lymphocytes are mainly in evidence, though some medium lymphocytes are also seen. Gradually, the size distribution of the labelled cells changes, so that in one experiment the size distribution during the first hour was $47: 7: 0$ (that is, 47 large, 7 medium and 0 small lymphocytes), in the second hour $48: 20: 0$, in the third hour $57: 35: 4$ and in the fourth $75: 64$ : 20. Labelled small lymphocytes began to appear during the third hour and then gradually increased. In the lymph of another animal, obtained at $14 \mathrm{hr}$. after thymidine, the size distribution among the labelled cells was $47: 75: 54$, and in lymph collected after $25 \mathrm{hr}$. it was $33: 65: 94$. After a single injection of thymidine, a steady stream of labelled lymphocytes, ranging from $2 \cdot 0$ to $7 \cdot 0$ per cent of the total thoracic duct cells, enters the blood over several days. These findings, which differ from those of Gowans ${ }^{4}$ in the rat, suggest the continuous liberation of cells from a precursor pool. Labelled small lymphocytes were also found in the blood by the seventh hour, and in view of the work of Bond et al. ${ }^{5}$, are presumably cells which have entered the blood after labelling in the lymphoid tissues.

Examination of the lymphoid tissues shows active synthesis of deoxyribonucleic acid from the outset, especially in the germinal centres. Though accurate quantitation is not yet possible, it seems clear that there is extensive new formation of lymphocytes; and that a large number of the small lymphocytes in thoracic duct lymph must be newly formed cells. The results do not support the concept either of massive re-utilization ${ }^{6}$ or large-scale recirculation ${ }^{7}$.

This work was supported in part by funds allocated to N. B. Everett through an institutional research grant from the American Cancer Society to the University of Washington, and by a U.S. Public: Health Services research grant (W. O. Reinhardt).

Department of Anatomy,

J. M. YoFFEY

The University, Bristol 8.

Department of Anatomy,

N. B. EvERETT

University of Washington School of Medicine, Seattle 5, Washington.

W. O. Reinhardt

Department of Anatomy,

University of California Medical School,

Berkeley 4, California.

1 Fitzgerald, P. J., Eidinoff, M. L., Knoll, J. E., and Simmel, E. B., Science, 114, 494 (1951).

${ }^{2}$ Reichard, P., and Estborn, B., J. Biol. Chem., 188, 939 (1951).

${ }^{3}$ Belanger, L. F, and Leblond, C. P., Endocrinol., 39, 8 (1946).

Gowans, L. J., Proc. Physiol. Soc., July 11-12 (1958).
B Bond, V. P., Cronkite, E. P., Fliedner, T. M., and Schork, P., Science, 128, 202 (1958).

${ }^{6}$ Hamilton, L. D., in "The Leukemias" edited by Rebuck, J. W., Bethel, F. H., and Monto, R. W., 381-400 (Academic Press Inc., New York, 1957).

" Sjövall, H., "Experimentelle Untersuchungen über das Biut und die blutbildenen Organe-besonders das Lymphatische Gewebe-des Kaninchens bei wiederholten Aderlässen" (Hakon Ohlssons Boktryckeri, Lund, 1936).

\section{Some Structural Characteristics of Myelinated Nerve Fibres}

IN a previous communication ${ }^{1}$ observations were made concerning some errors attendant on methods which have been used in the quantitative examination of myelinated nerve fibres.

A technique demonstrated ${ }^{2}$ to the Anatomical Society of Great Britain and Ireland on February 28 has been used to investigate the size relation of the axon and its myelin sheath ${ }^{3}$. During examination of the sural nerve and the nerve to the medial head of the gastrocnemius muscle of the rabbit some points of general interest not previously published have emerged.

$5-\mu$ transverse sections of fresh nerve were examined using a polarizing microscope, and measurements of axonal and external diameter made.

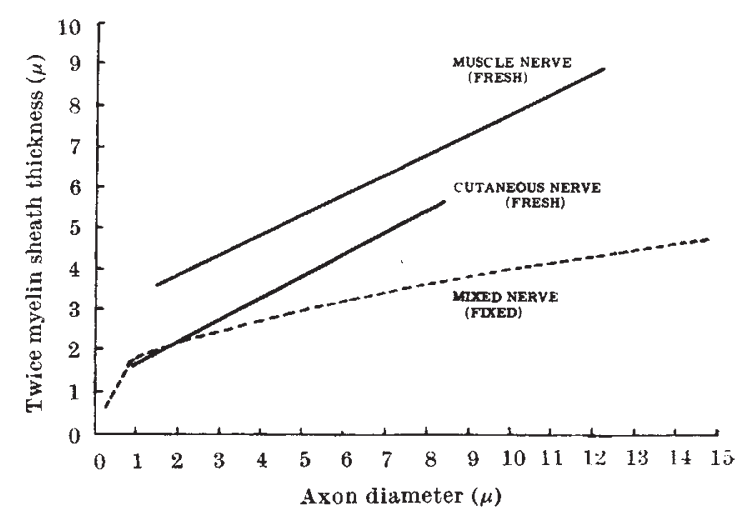

Fig. 1. Composite graph of twice myelin sheath thickness against axon diameter for a muscle nerve and a cutaneous nerve stained fibres of the mixed peroneal nerve of the rabbit is included for comparison 